\title{
PENERAPAN METODE PEMBELAJARAN IMAJINATIF DALAM MENINGKATKAN PRESTASI BELAJAR MENGARANG BAHASA INDONESIA PADA SISWA KELAS VIII A SMP NEGERI 20 BENGKULU SELATAN TAHUN PELAJARAN 2016/2017
}

\author{
Risdi Yasik
}

\section{risdiyasik@gmail.com}

\begin{abstract}
Abstrak
Dalam kegiatan pembelajaran selalu dijumpai adanya peserta didik yang mengalami kesulitan dalam mencapai standar kompetensi, kompetensi dasar, dan penguasaan materi pembelajaran yang telah ditentukan. Secara garis besar kesulitan yang dimaksud dapat berupa kurangnya pengetahuan prasyarat, kesulitan memahami materi pembelajaran, maupun kesulitan dalam mengerjakan tugas-tugas latihan dan menyelesaikan soal-soal ulangan. Secara khusus, kesulitan yang dijumpai peserta didik dapat berupa tidak dikuasainya kompetensi dasar mata pelajaran tertentu, misalnya operasi bilangan dalam matematika, atau membaca dan menulis dalam pelajaran bahasa Indonesia. Agar peserta didik dapat memecahkan kesulitan tersebut perlu adanya bantuan. Bantuan dimaksud berupa pemberian pembelajaran remedial atau perbaikan. Untuk keperluan pemberian pembelajaran remedial perlu dipilih strategi dan langkah-langkah yang tepat setelah terlebih dahulu diadakan diagnosis terhadap kesulitan belajar yang dialami peserta didik. Tujuan diadakan penelitian tindakan kelas (PTK) ini adalah untuk mengetahui peningkatan prestasi belajar siswa dengan menggunakan pembelajaran Imajinatif. Penelitian ini dilakukan dalam 3 siklus. Dari hasil tindakan yang dilakukan terbukti dapat meningkatkan prestasi siswa dengan mencapai standar ideal. Dari $70.58 \%$ pada siklus 1, dapat meningkat pada siklus 2 menjadi $75.33 \%$ dan siklus 3 mencapai $79.88 \%$ dan secara klasikal telah mencapai ketuntasan. Hasil penelitian tindakan menunjukkan bahwa pembelajaran Imajinatif dapat meningkatkan prestasi belajar siswa kelas VIII A dengan ketuntasan mencapai $100 \%$ dengan demikian Penerapan Pembelajaran Imajinatif Efektif dalam Meningkatkan Prestasi Belajar Siswa Pelajaran Bahasa Indonesia di SMP Negeri 20 Bengkulu Selatan.
\end{abstract}

Kata Kunci: Pembelajaran Imajinatif, Prestasi Belajar Siswa, Pelajaran Bahasa Indonesia SMP

\begin{abstract}
In learning activities always found the students who have difficulty in achieving the standard of competence, basic competence, and mastery of learning materials that have been determined. Broadly speaking the difficulty can be a lack of prerequisite knowledge, difficulty understanding learning materials, or difficulty in doing the exercises and solving repetition questions. In particular, the difficulties encountered by learners may include the lack of competence of a particular subject, such as numerical operations in mathematics, or reading and writing in Indonesian language. In order for learners to solve these difficulties need help. Such assistance shall be in the form of remedial or remedial instruction. For the purposes of providing remedial learning should be chosen strategies and steps appropriate after first held a diagnosis of learning difficulties experienced by learners. The purpose of this classroom action research (PTK) is to determine the improvement of student achievement by using Imaginative learning. This study was conducted in 3 cycles. From the
\end{abstract}


results of actions performed proven to improve student achievement by achieving the ideal standard. From $70.58 \%$ in cycle 1, it can increase in cycle 2 to $75.33 \%$ and cycle 3 reaches $79.88 \%$ and has by-passed completion. The results of action research show that Imaginative learning can improve student achievement class VIII A with completeness reach $100 \%$ thus Implement Imaginative Learning Effective in Improving Student Achievement of Indonesian Language Lesson in SMP Negeri 20 Bengkulu Selatan.

\section{Keywords: Student Learning Achievement, Indonesian Language Lesson in Junior High School, Imaginative Learning}

\section{PENDAHULUAN}

Ada tiga aspek dalam pengajaran Bahasa Indonesia yang perlu diperhatikan, yaitu aspek pengetahuan/kompetensi, skill dan sikap. Ketiga aspek Itu berturut-turut menyangkut ilmu pengetahuan, perasaan, dan keterampilan atau Kegiatan berbahasa. Ketiga aspek tersebut harus berimbang agar tujuan pengajaran Bahasa yang sebenarnya dapat dicapai.

Bahasa Indonesia erat kaitannya dengan guru bahasa Indonesia. Berhasil atau tidaknya pengajaran Bahasa Indonesia memang diantaranya ditentukan oleh faktor guru, disamping faktor-faktor Lainnya, seperti faktor murid, metode pembelajaran, kurikulum (termasuk silabus), Bahan pengajaran dan buku, serta yang tidak kalah pentingnya ialah perpustakaan sekolah dengan disertai pengelolaan yang memadai.

Bahasa Indonesia diajarkan di sekolah lanjutan, bahkan sampai sekolah tinggi. Keterampilan berbahasa Indonesia perlu mendapatkan tekanan yang Lebih banyak lagi, mengingat kemampuan berbahasa Indonesia di kalangan pelajar Ini juga disebabkan oleh kualitas guru, dari pihak lain munculnya anggapan bahwa Setiap orang Indonesia pasti bisa berbahasa Indonesia.

Sudah bukan rahasia lagi dan seolah-olah sudah menjadi asumsi umum bahwa hasil pengajaran bahasa Indonesia di sekolah-sekolah dari sekolah lanjutan sampai menengah sampai sekolah lanjutan kurang memuaskan. " Masalah yang dimaksud adalah dilihat dari hasil ujian sebagai salah satu barometer keberhasilan pengajaran bahasa Indonesia. Kenyataan tersebut juga pernah penulis jumpai dalam beberapa kali pengalaman mengoreksi hasil ujian mengarang bahasa Indonesia pada siswa sekolah lanjutan sampai menengah. Dari hasil karangan para siswa tersebut banyak sekali penulis jumpai kelemahan-kelemahan siswa dalam penguasaan unsur-unsur pembentuk karangan itu sendiri. Terlepas dari faktorfaktor lain dari kenyataan tersebut, kita dapat berasumsi bahwa pembelajaran bahasa Indonesia khususnya mengarang masih perlu mendapatkan perhatian lebih serius dari para guru bahasa Indonesia.

Pelajaran mengarang sebenarnya sangat penting diberikan kepada murid untuk melatih menggunakan bahasa secara aktif. Di samping itu, pengajaran mengarang di dalamnya secara otomatis mencakup banyak unsur kebahasaan termasuk kosa kata dan keterampilan penggunaan bahasa itu sendiri dalam bentuk bahasa tulis. Akan tetapi dalam hal ini guru bahasa Indonesia dihadapkan pada dua masalah yang sangat dilematis. Di satu sisi guru bahasa harus dapat menyelesaikan target kurikulum yang harus dicapai dalam kurun waktu yang telah ditentukan. Sementara disisi lain porsi waktu yang disediakan mata pelajaran mengarang relatif terbatas, padahal untuk pelajaran mengarang seharusnya dibutuhkan waktu yang cukup panjang, karena diperlukan latihan-latihan 
yang cukup untuk memberikan siswa dalam karang-mengarang. Dari dua dua persoalan tersebut kiranya dibutuhkan kreativitas guru untuk mengatur sedemikian rupa sehingga materi pelajaran mengarang dapat diberikan semaksimal mungkin dengan tidak mengesampingkan materi yang lain.

Sekolah kita pada umumnya agak mengabaikan pelajaran mengarang. Ada beberapa faktor penyebabnya yaitu, (1) sistem ujian yang biasanya menjabarkan soal-soal yang sebagiaqn besar bersifat teoritis, (2) kelas yang terlalu besar dengan jumlah murid berkisar antara empat puluh sampai lima puluh orang.

Materi ujian yang bersifat teoritis dapat menimbulkan motivasi guru bahasa mengajarkan materi mengarang hanya untuk dapat menjawab soal-soal ujian, sementara aspek keterampilan dapat diabaikan. Sedangkan dengan kelas yang besar konsekkuensi biasanya guru enggan memberikan pelajaran mengaran, karena ia harus memeriksa karangan muridmuridnya yang berjumlah mencapai empat puluh sampai lima puluh lembar, kadang hal itu masih harus berhadapan dengan tulisan-tulisan siswa yang notabene sulit dibaca. Belum lagi ia harus mengajar lebih dari satu kelas atau mengajar di sekolah lain, berarti yang harus diperiksa empat puluh kali sekian lembar karangan. Oleh karena itu, tidak jarang guru yang menyuruh muridnya mengarang hanya sebulan sekali atau bahkan sampai berbulan- bulan.

Disamping hal-hal tersebut, ada asumsi sebagian guru yang menganggap tugas mengarang yang diberikan pada siswa terlalu memberatkan atau tugas itu terlalu berat untuk siswa, sehingga ia merasa kasihan memberikan beban berat tersebut kepada siswanya. la terlalu pesimis dengan kemampuan muridnya. Asumsi tersebut tidak bisa dibenarkan, karena justru dengan seringnya latihanlatihan yang diberikan akan membuat siswa terbiasa dengan hal itu. Kita tahu bahwa keterampilan berbahasa akan dapat dicapai dengan baik bila dibiasakan. Kalau guru selalu dihantui oleh perasaan ini dan itu, bagaiman muridnya akan terbiasa menggunakan bahasa dengan sebaikbaiknya.

Berdasarkan paparan tersebut, maka dalam penelitian ini diberi judul "Penerapan Metode Pembelajaran Imajinatif dalam Meningkatakan Prestasi Belajar Mengarang Bahasa Indonesia Pada Siswa Kelas VIII A SMP Negeri 20 Bengkulu Selatan Tahun Pelajaran 2016-2017".

\section{Pengertian Prestasi}

Prestasi belajar adalah hasil atau akibat dari kegiatan belajar. Untuk mengetahui tentang prestasi belajar perlu dijelaskan tetang hakekat belajar. Belajar merupaka suatu proses yang dilakukan seseorang untuk memperoleh suatu perubahan tingkah laku yang baru secara keseluruhan sebagai hasil pengalaman (Slameto, 2003:22). Perubahan itu bersifat kontinyu dan fungsional, terjadi secara sadar, bersifat positif dan aktif, bukan bersifat sementara.bertujuan atau terarah,dan mencakup seluru aspek tingkah laku yang selanjutnya dinamakan hasil belajar. Hasil belajar tersebut dapat dinyatakan dalam bentuk prestasi belajar. Menurut Skinner (dalam Sutikno,2007:5), belajar adalah suatu proses adaptasi atau penyesuaian tingkah laku yang berlangsung secara progresif. Berdasarkan pengertian di atas, maka dapat didefenisikan tentang prestasi belajar, yaitu tingkat keberhasilan yang dicapai siswa berupa ketrerampilan dan pengetahuan berdasarkan hasil tes atau evaluasi setelah pelaksanaan proses belajar mengajar.

Sedangkan ketuntasan belajar merupakan hasil belajar siswa yang memenuhi kreteria standar tertentu. Seorang siswa dikatakan tuntas belajar bila mencapai ketuntasan indikator hasil belajar $\geq 75 \%$,dan dari suatu kelas dikatakan 
tuntas belajar bila dalam kelas telah mencapai $\geq 85 \%$ siswa yang telah tuntas belajar (Natawijaya,1997).

\section{Faktor-faktor yang Mempengaruhi Prestasi Belajar \\ Faktor Internal}

Faktor intern adalah faktor yang berasal dari dalam diri individu. Faktor ini juga merupakan atribut atau aspek-aspek yang melekat secara individual pada kepribadian anak didik baik yang bersifat rohania maupun yang bersifat jasmaniah, dimana pada umumnya yang bersifat rohaniah tersebut merupakan sifat-sifat yang terbawa sejak lahir, umpamanya intelegensi, bakat,minat, motif dan lainlain, namun demikian faktor-faktor dimaksud ada yang dapat mempengaruhi dari luar. Tetapi ada pula yang bersifat konsisten (tetap) tanpa dapat dibimbing oleh faktor lingkungan, misalnya intelegensi dan bakat. Lingkungan dalam arena ini pada umumnya hanya berperan untuk mengoptimalkan aspek-aspek tersebut. Tanpa adanya bakat yang dibawa sejak lahir, lingkungan tidak dapat menciptakan seseorang untuk dapat berbuat yang baik sesuai dengan kualitas karakteristik tindakan-tindakan dimaksud.

Orang mengenal dunia sekitarnya dan belajar dengan mempergunakan pancainderanya. Baiknya fungsi pancaindera pula. Dalam sistem persekolahan dewasa ini diantara pancaindera itu yang paling memegang peranan dalam belajar adalah mata dan telinga (Suryabrata, 1984:156).

\section{Faktor Eksternal}

Faktor ekstern adalah faktor yang berasal dari luar diri individu. Faktor eksternal juga dapat dipahami sebagai unsur-unsur yang terdapat di sekitar subyek yang sedang belajar. Karena dalam faktor eksternal ini terdapat berbagai variabel yang dapat dikatagorikan pada masalah ini, hal ini dapat berbentuk fisik dan tidak sedikit yang bersifat nonfisi. Aktualisasi faktor eksternal dalam belajar dapat dikelompokkan menjadi 3 faktor, yaitu faktor keluarga, sekolah, dan faktor masyarakat (Slameto, 2003:62). Dari 3 faktor tersebut disederhanakan menjadi faktor lingkungan sosil dan faktor lingkungan non-sosial.

\section{Faktor Lingkungan Sosial}

Yang termasuk faktor lingkungan sosial adalah masyarakat dan tetangga juga teman sepermainan (Muhibbin, 2003:137). Lingkungan sosial masyarakat dapat dibagi menjadi dua yaitu lingkungan sosial masyarakat tempat siswa tinggal seperti orang tua, adik, kakak, dan lain-lain, dan lingkungan sosial masyarakat tempat siswa belajar seperti guru,teman belajar, dan lain-lain. Faktor -faktor tersebut sangat mempengaruhi prestasi belajar siswa.

\section{Faktor Lingkungan Non-sosial}

Faktor yang termasuk nonsosial adalah gedung sekolah dan letaknya, rumah tempat tinggal keluarga dan letaknya, alat belajar, keadaan cuaca, dan waktu belajar yang digunakan (Muhibbin, 2003:138).

\section{Pembelajaran Bahasa Indonesia di SMP Pengertian Bahasa}

Manusia merupakan makhluk yang perlu berinteraksi dengan manusia lainnya. Intraksi terasa semakin penting pada saat manusia membutuhkan eksistensinya. Diakui kegiatan ini membutuhkan alat, saran, atau media yaitu bahasa."Bahasa adalah alat komunikasi antar anggota masyarakat berupa simbol bunyi yang dihasilkan oleh alat ucap manusia" (Keraf, 2004:1).

\section{Pembelajaran Imajinatif \\ Model Pembelajaran Menulis Imajinatif merupakan pembelajaran lanjutan setelah Model Pembelajaran}


Menulis Rekreasi dan merupakan tataran tertinggi dalam pembelajaran menulis/mengarang.Dalam proses pembelajaran menulis Imajinatif ini siswa diajarkan menguasai kompetensi menulis/mengarang secara bebas sesui imajinasinya sendiri-sendiri. Di sini siswa diberi kebebasan untuk menuangkan segala ide/ gagasan, pendapat/openi, imajinasi atau daya khayal, dsb kedalam bentuk tulisan/ karangan. Adapun pemilihan metode dan media pembelajarannya tergantung situasi pembelajaran seperti apa yang dikehendaki/diinginkan, dan relevansinya dengan tujuan pembelajaran /KDnya.

\section{Hipotesis Penelitian}

Dari uraian tersebut di atas, maka hipotesis tindakan dalam penelitian ini adalah sebagai berikut :

1. Prestasi belajar mengarang Bahasa Indonesia dapat ditingkatkan melalui metode pembelajaran Imajinatif pada siswa kelas VIII A SMP Negeri 20 Bengkulu Selatan Tahun Peljaran 20162017?

2. Metode pembelajaran Imajinatif efektiv dalam Meningkatkan prestasi belajar mengarang Bahasa Indonesia pada siswa kelas VIII A SMP Negeri 20 Bengkulu Selatan Tahun Pelajaran 2016-2017?

\section{METODE}

Subyek penelitian ini adalah peningkatan prestasi belajar siswa dalam pelajaran Bahasa Indonesia melalui pembelajaran remedial di SMP Negeri 20 Bengkulu Selatan. Berdasarkan hasil observasi yang penulis lakukan bahwa kelas VIII A prestasi belajar siswa dalam pelajaran Bahasa Indonesia masih sangat rendah. Siswa merasa kesulitan dalam belajar sehingga siswa kurang respon terhadap pembelajaran di kelas. Penelitian ini merupakan penelitian tindakan kelas, yang dilakukan secara bertahap-tahap sampai mendapatkan hasil yang diinginkan.

\section{HASIL DAN PEMBAHASAN}

Hasil

Pelaksanaan tindakan dalam penelitian dilakukan 3 siklus yang terdiri dari tiga kali pertemuan. Waktu yang digunakan setiap kali pertemuan adalah $2 \mathrm{x}$ 40 menit. Pertemuan pertama dilaksanakan pada tanggal 12 s.d 19 Januari 1017 dan pertemuan kedua pada tanggal 26 Januari s.d 03 Februari 2017.dan pertemuan ketiga 10 s.d 17 Februari 2017. Penelitian tindakan kleas dilaksanakan sesuai dengan prosedur rencana pembelajaran dan skenario pembelajaran.

\section{SIKLUS I}

a) Tahap perencanaan

Pada tahap ini peneliti mempersiapkan perangkat pembelajaran yang terdiri dari rencana pembelajaran 1, LKS I, soal tes formatif 1 dan alat-alat pengajaran yang mendukung. Selain itu juga dipersiapkan lembar observasi pengolaan pembelajaran.

b) Tahap Kegiatan dan pelaksanaan

Pelaksanaan kegiatan belajar mengajar untu siklus 1 dilaksanakan pada tanggal 12 s.d. 19 Januari 2017 di SMP Negeri 20 Bengkulu Selatan tahun pelajaran 2016/2017. Adapun jumlah siswa 24 orang. Dalam hal ini, peneliti bertindak sebagai guru.

Adapun proses belajar mengajar mengacu pasda rencana pelajaran yang telah dipersiapkan. Penganmatan (observasi) dilaksanakan bersamaan dengan pelaksanaan belajar mengajar. Pada akhir proses belajar mengajar siswa diberi tes formatif 1 dengan tujuan untuk mengetahui tingkat keberhasilan siswa dalam proses belajar mengajar yang telah dilakukan. 
Berdasarkan hal di atas pembelajaran dengan Imajinatif diperoleh nilai rata-rata prestasi belajar siswa adalah $70.58 \%$ atau ada 9 siswa dari 24 siswa sudah tuntas belajar. Hasil tersebut menunjukkan bahwa pada siklus pertama secara klasikal siswa belum tuntas belajar, karena siswa yang yang mmperoleh nilai $\geq 76$ hanya sebesar $33,33 \%$, lebih kecil dari porsentase ketuntasan yang dikehendaki yaitu sebesar $85 \%$. Hal ini disebabkan karena siswa masih merasa baru dan belum mengerti apa yang dimaksudkan dan digunakan guru dengan menggunakan pembelajaran imajinatif.

c) Refleksi

Dalam pelakasanaan kegiatan belajar mengajar diperoleh informasi dari hasil pengamatan sebagai berikut:

1. Guru kurang baik dalam memotivasi siswa dan dalam menyampaikan tujuan pembelajaran

2. Guru kurang baik dalam pengelolaan waktu

3. Siswa kurang begitu antusias selama pembelajaran berlangsung.

d) Revisi Rancangan

Pelaksanaan kegiatan belajar mengajar pada siklus I ini masih terdapat kekurangan, sehingga perlu adanya revisi untuk dilakukan pada siklus berikutnya.

1. Guru perlu lebih tranpil dalam memotivasi siswa dan lebih jelas dalam menyampaiakntujuan pembelajaran. Di mana siswa diajak untuk terlibat langsung dalam setiap kegiatan yang akan dilakukan.

2. Guru perlu menditribusikan waktu secara baik dengan menanbahkan informasi-informasi yang diras perlu dan membericatatan.
3. Guru harus lebih teranpil dan bersemangat dalam memotivasi siswa sehingga siswa lebih antusias.

\section{SIKLUS II}

a) Tahap Perencanaan

Pada tahap ini peneliti mempersiapkan perangkat pembelajaran yang terdiri dari, rencana pembelajar 2, soal tes formatif II dan alat-alat pengajaran yang mendukung.

b) Tahap Kegiatan dan Pelaksanaan

Pelaksanaan kegiatan belajar mengajar untuk siklus II dilaksanakan pada tanggal 26 Januari s.d. 03 Februari 2017 di SMP Negeri 20 Bengkulu Selatan tahun pelajaraqn 2016-2017. Dalam hal ini peneliti bertindak sebgai guru. Adapun proses belajar mengajar mengacu pada rencana pembelajaran dengan memperhatikan revisi pada siklus I. Sehingga kesalahan atau kekurangan pada siklus I tidak terulang lagi pada siklus II. Pengamatan (observasi) dilaksanakan bersamaan dengan pelaksanaan belajar mengajar

Pada akhir proses belajar mengajar siswa diberi tes formati II dengan tujuan untuk mengetahui tingkat keberhasilan siswa dalam proses belajar mengajar yang telah dilakukan. Instrumen yang digunakan adalah tes formati II

Dari hal di atas diperoleh nilai ratarata prestasi belajar siswa adalah $75.33 \%$ dan ketuntasan belajar mencapai 81,82 \% atau ada 18 siswa dari 24 siswa sudah tuntas belajar. Hasil ini menunjukkan bahwa pada siklus II ini ketuntasan belajar secara klasikal telah mengalami peningkatan cukup lebih baik dari siklus I. Adanya peningkatan hasil belajar siswa ini karena setelah guru menginformasikan bahwa setiap akhir pelajaran akan 
selalu diadakan tes sehingga pada pertemuan berikutnya siswa lebih termotivasi untuk belajar. Selain itu siswa juga sudah mulai mengerti apa yang dimaksudkan dan diinginkan guru dalam menerapkan pembelajaran Imajinatif.

c) Refleksi

Dalam pelaksanaan kegiatan belajar diperoleh informasi dari hasil pengamatan sebagai berikut :

1. Memotivasi siswa

2. Membimbing siswa merumuskan kesimpulan/ menemukan konsep

3. Pengelolaan Waktu

d) Revisi Pelaksanaan

Pada pelaksanaan kegiatan belajar pada siklus II ini masih terdapat kekurangan-kekurangan. Maka perlu adanya revisi untuk dilaksanakan pada siklus III antara lain :

1. Guru dalam memotivasi siswa hendaknya dapat membuat siswa lebih termotivasi selama proses belajar mengajar berlangsung.

2. Guru harus lebih dekat dengan siswa sehingga tidak ada perasaan takut dalam diri siswa baik untuk mengemukakan pendapat atau bertanya

3. Guru harus lebih sabar dalam membimbing siwa merumuskan kesimpulan/menemukan konsep.

4. Guru harus mendistribusikan waktu secara baik sehingga kegiatan pembelajaran dapat berjalan sesuai dengan yang diharapkan.

5. Guru sebaiknya menambah lebih banyak contoh soal dan memberi soal- soal latihan pada siswa untuk dikerjakan pada setiap kegiatan belajar mengajar.

\section{SIKLUS III}

a) Tahap Perencanaan
Pada tahap ini peneliti mempersiapakan perangkat pembelajaran yang terdiri dari erencana pembelajaran 3 , soal tes formatif 3 dan alat-alat pengajaran yang mendukung.

b) Tahap Kegiatan dan Pengamatan

Pelaksanaan kegiatan belajar mengajar untuk siklus III dilaksanakan i pada tanggak 10 s.d 17 Februaru 2017 di SMP Negeri 20 Bengkulu Selatan tahun pelajaranb 2016-2017 dengan jumlah siswa 24 siswa.

Dalam hal ini peneliti bertindak guru. Adapun proses belajar mengajar mengacu rencana pembelajaran dengan memperhatikan revisi pada siklus II, sehingga kesalahan atau kekurangan pada siklus II tidak terulang lagi pada siklus III. Pengamatan (obsevasi ) dilaksanakan dengan bersamaan dengan pelaksanaan belajar mengajar.

Pada akhir proses belajar mengajar siswa diberi tes formatif 3 dengan tujuan untuk mengetahui tingkat keberhasilan siswa dalam proses belajar mengajar yang telah dilakukan.

Berdasarkan tabel di atas diperoleh nilai rata-rata tes formatif sebesra $79.88 \%$ dari 24 siswa telah tuntas secara keselutuhan. Maka secara klasikal ketuntasan belajar yang telah tercapai sebesar $100 \%$ (termasuk katagori tuntas). Hasil pada siklus III ini mengalami peningkatan lebih baik dari siklus II. Adanya peningkatan hasil belajar pada siklus III ini dipengaruhi oleh adanya peningkatan kemampuan guru dalam menerapakn pembelajaran Imajinatif pada pelajaran Bahasa Indonesia, sehingga siswa menjadi lebih terbiasa dengan pelajaran seperti ini sehingga siswa lebih mudah dalam memahami materi yang telah diberikan. Di samping itu ketuntasan ini juga dipengaruhi oleh kerja sama 
dari siswa yang telah menguasai materi pelajaran untuk mengajari temannya yang belum menguasai.

c) Refleksi

Pada tahap ini akan dikaji apa yang telah terlaksana dengan baik dalam prosews belajar mengajar dengan penerapan media rekaman. Dari datadata yang telah diperoleh dapat diuraikan sebagai berikut:

1. Selama proses belajar mengajar guru telah melaksanakan semua pembelajaran dengan baik. Meskipun ada beberapa aspek yang belum sempurna, tetapi persentase pelaksanaannya untuk masingmasing aspek cukup besar.

2. Berdasarkan data hasil pengamatan diketahui bahwa siswa aktif selama proses belajar berlangsung.

3. Kekurangan pada siklus-siklus sebelumnya sudah mengalami perbaikan dan peningkatan sehingga menjadi lebih baik.

4. Hasil belajar siswa pada siklus III mencapai ketuntasan.

d) Revisi Pelaksanaan

Pada siklus III guru telah menerapkan media rekaman, dengan baik dan dilihat dari aktivitas siswa serta hasil belajar siswa pelaksanaan proses belajar mengajar sudah berjalan dengan baik. Maka tidak diperlukan revisi terlalu banyak, tetapi yang perlu diperhatiakan untuk tindakan selanjutnya adalah memaksimalkan dan mempertahankan apa yang telah ada dengan tujuan agar pada pelaksanaan proses belajar mengajar selanjutnya penerapan pembelajaran Imajinatif, dapat meningkatkan proses belajar mengajar sehingga tujuan pembelajaran dapat tercapai.

\section{Analisis Hasil Kegiatan}

Setelah dilakukan tindakan pada siklus I, siklus 2 dan silus 3 menunjukkan hasil sebagai berikut.

\section{Analisis Data Deskriftif Kuantitatif}

1. Pencapaian hasil belajar siswa sebelum diberi tindakan :

$$
=\frac{1694 \times 100 \%}{2400}=70.58 \%
$$

2. Pencapaian hasil belajar siswa setelah diberi tindakan pengelompokan siswa

Berdasarkan nomor panggilan (acak berdasarkan tempat duduk)

$$
=\frac{1808 \times 100 \%}{2400}=75.33 \%
$$

3. Pencapaian hasil belajar siswa setelah diberi tindakan pengelompokan siswa

Berdasarkan kemampuan akademik

$$
=\frac{1917 \times 100 \%}{2400}=79.88 \%
$$

Dari hasil analisis tersebut dapat disimpulkan bahwa:

1. Terjadi peningkatan prestasi setelah diberi tindakan yaitu $70.58 \%$ menjadi $75.33 \%$ ada kenaikan sebesar $6.72 \%$

2. Dari sebelum tindakan untuk materi menyimak (siklus I) dan setelah tindakan sampai dengan (siklus 2) $70.58 \%$ menjadi $75.33 \%$, dan dari (siklus 2) ke (siklus 3) juga ada peningkatan sebanyak $79.88 \%$ $75.58 \%=455 \%$

3. Rata-rata siswa sebelum diberi tindakan $33.33 \%$ (siklus I) naik $81.82 \%$ siklus II, dan siklus III meningkat menjadi $100 \%$.

\section{Refleksi dan Temuan}

Berdasarkan hasil dan pembahasan dapat disimpulkan bahwa:

a. Pertemuan pertama kegiatan belajar mengajar menerapkan pembeljaran Imajinatif belum berhasil karena dalam pembelajaran masih terlihat siswa yang bermain, bercerita, dan mengganggu siswa lain

b. Model pembelajaran dengan Imajinatif, dalam hal peningkatan 
prestasi belum tanpak, sehingga hasil yang dicapai tidak tuntas

c. Mungkin karena proses belajar mengajar yang dilakukan adalah Pembelajaran Imajinatif yang baru mereka laksanakan sehingga siswa siswa merasa kaku dalam menerapkannya

Akan tetapi setelah dijelaskan, mereka bisa mengerti dan buktinya pada pertemuan kedua dan ketiga proses kegiatan belajar-mengajar berjalan baik, semua siswa aktif dan lebih- lebih setelah ada rubrik penilaian proses seluruh siswa langsung aktif belajar.

\section{Pembahasan}

1. Ketuntasan Hasil Belajar Siswa

Berdasarkan hasil penelitian ini menunjukkan bahwa penerapan Pembelajaran Imajinatif memiliki danpak positif dalam meningkatkan prestasi belajar siswa. Hal ini dapat dilihat dari semakin mantapnya pemahaman siswa terhadap materi yang disampaikan guru (ketuntasan belajar meningkat dari siklus I, II, dan III) yaitu $70.58 \% ; 75.33 \% ; 79.88 \%$. Pada siklus III ketuntasan belajar siswa secara klasikal telah tercapai.

2. Kemampuan Guru dalam Mengelola Pembelajaran

Berdaarkan analisis data, diperoleh aktivitas siswa dalam proses pembelajaran imajinatif dalam setiap siklus mengalami peningkatan. Hal ini berdampak positif terhadap prestasi belajar siswa yaitu dapat ditunjukkan dengan meningkatnya nilai rata-rata siswa pada setiap siklus yang terus mengalami peningkatan.

3. Aktivitas Guru dan Siswa dalam Pembelajaran

Berdasarkan analisis data, diperoleh aktivitas siswa dalam proses pembelajaran imajinatif yang paling dominan adalah bekerja dengan menggunakan alat/media, mendengarkan/memperhatikan

penjelasan guru, dan diskusi antar siswa/antara siswa dengan guru. Jadi dapat dikatakan bahwa aktivitas siswa dapat dikatagorikan

Aktif, sedangkan untuk aktivitas guru selama pembelajaran telah melaksanakan langkah-langkah pembelajaran imajinatif dengan baik. Hal ini terlihat dari aktivitas guru yang muncul di antaranya aktivitas memimbing dan mrngamati siswa dalam mengerjakan kegiatan pembelajaran, menjelaskan, memberi umpan balik/evaluasi/tanya jawab di mana persentase untuk aktivitas di atas cukup besar.

Berdasarkan hasil penelitian di atas, maka hasil belajar siswa untuk pelajaran Bahasa Indonesia dengan menggunakan pembelajaran imajinatif hasilnya sangat baik. Hal itu tanpak pada pertemuan pertama dari 24 orang siswa yang hadir pada saat penelitian ini dilakukan nilai rata-rata mencapai; $70.58 \%, 75.33 \%$, ; $79.88 \%$

Berdasarkan analisis data di atas bahwa pembelajaran imajinatif pada pelajaran Bahasa Indonesia materi belajar mengarang kelas VIII A, yang berarti proses kegiatan belajar mengajar lebih berhasil dan dapat meningkatkan prestasi belajar khususnya pada siswa kelas VIII A di SMP Negeri 20 Bengkulu Selatan. Oleh karena itu diharapkan para guru SMP dapat melaksanakan pembelajaran imajinatif di kelas VIII A.Berdasarkan kurikulum tingkatan satuan pendidkan ( KTSP) siswa dikatakan tuntas apabila siswa telah mencapai nilai standar ideal 75 mencapai $\geq 85 \%$ sedangkan pada penelitian ini pencapaian nilai $\geq 75$ pada (siklus 3) mencapai melebihi target yang ditetapkan dalam KTSP yaitu mencapai $100 \%$. Dengan demikian, maka hipotesis yang diajukan dapat diterima. 


\section{PENUTUP}

Kesimpulan

Berdasarkan hasil kegiatan

pembelajaran yang telah dilakukan selama tiga siklus, dan seluruh pembahasan serta analisis yang telah dilakukan dapat disimpulkan bahwa:

1. Pembelajaran bahasa Indonesia dengan menggunakan Pembelajaran Imajinatif memiliki dampak positip dalam meningkatkan prestasi belajar siswa SMP Negeri 20 Bengkulu Selatan yang ditandai dengan peningkatan ketuntasan belajar setiap siklus, yaitu; 70.58 \% (siklus I ), ; 75.33 \% (siklus II), 79.88 (siklus III).

2. Penerapan pembelajaran Imajinatif pada pelajaran Bahasa Indonesia materi menulis paragraf narasi mempunyai pengaruh positif, yaitu dapat meningkatkan prestasi belajar siswa.

3. Penerapan pembelajaran Imajinatif ifektif dalam mengingatkan kembali materi ajar yang telah diterima oleh siswa selama ini, sehingga mereka merasa siap untuk menghadapi pelajaran berikutnya.

\section{Saran}

Dari hasil penelitian yang diperoleh dari uraian sebelumnya agar proses belajar mengajar di sekolah menengah pertama (SMP) lebih efektif dan lebih memberikan hasil yang optimal bagi siswa, maka disampaikan saran sebagai berikut:

1. Untuk melaksanakan pembelajaran memerlukan persiapan yang cukup matang, sehingga guru harus mampu menentukan atau memilih topik yang benar-benar bisa diterapkan dengan menggunakan Imajinatif sehingga diperoleh hasil yang optimal.

2. Dalam rangka meningkatakan prestasi belajar siswa, guru hendaknya lebih sering melatih siswa dengan kegiatan penemuan, walau dalam taraf yang sederhana, di mana siswa nantinya dapat menemukan pengetahuan baru, memperoleh konsep dan keterampilan, sehingga siswa berhasil atau mampu memecahkan masalahmasalah yang dihadapinya.

3. Perlu adanya penelitian yang lebih lanjut, karena hasil penelitian ini hanya dilakukan di SMP Negeri 20 Bengkulu Selatan tahun pelajaran 2016-2017.

\section{DAFTAR PUSTAKA}

Keraf, G. 2004. Komposisi. Semarang: Nusa Indah.

Natawijaya, R. 1997. Mengajar Belajar Matematik. Jakarta: Dirjen Dikti P2LPTK Depdikbud.

Slameto, 2003. Belajar dan Faktor-faktor yang Mempengaruhinya. Jakarta: Bina Aksara.

Suryabrata, S. 2003. Metodologi Research. Jakarta: Renika Cipta.

Sutikno, S., dkk. 1997. Strategi Belajar Mengajar Melalui Penanaman Konsep Umum dan Konsep Islami. Bandung: Refika Aditama.

Muhibbin, S. 2003. Psikologi Belajar. Jakarta: Raja Grafindo Persada. 